\title{
IMPLEMENTATION OF INTEGRATED DESIGN SYSTEMS IN THE LEARNING PROCESS
}

\author{
Sukhoi State Technical University of Gomel, Gomel, Republic of Belarus
}

\begin{abstract}
The modern stage of development of CAD-systems is characterized by a significant expansion of the scope of their use. An interesting direction for improving CAD systems is their integration with CAM systems. One of the main tasks solved by CAM systems is the development of control programs for CNC machines. Many software developers for automation of design and technological preparation of production have already equipped their systems with appropriate modules. These circumstances pose an urgent task for higher educational institutions to introduce the study of integrated CAD/CAM systems into the educational process of training design engineers. In this case, the emphasis should be placed on the practical mastery of the skills of developing control programs using a 3D-model of the manufactured part. The stages of preparation for the implementation of the system are described, starting with the analysis of the market of necessary software products and ending with the adaptation of the licensed system to the conditions of use in the educational process of the university. A link is given to the description of the methodology used in the assessment of automated systems at the stage preceding the tender for their purchase. It is emphasized that the study of the possibility of using a CAD/CAM system in the preparation of design engineers was carried out by students during the course and diploma projects in the discipline "Automated systems for technological preparation of production". The methodology for designing control programs used by students is given, and the results obtained are assessed.
\end{abstract}

Keywords: training of design engineers, control software, CAD/CAM system, software-controlled equipment.

\section{Introduction}

The modern stage of development of CAD-systems (Computer-Aided Design) is characterized by a significant expansion of the scope of their use. Now it is quite simple to obtain a 3D model of a part from a 2D drawing (and, vice versa), while it became possible to quickly and accurately determine a number of parameters, such as the weight of the part, its surface area, coordinates of the center of gravity and moments of inertia relative to the $\mathrm{X}$, $\mathrm{Y}, \mathrm{Z}$ axes. An interesting direction for improving CAD-systems is their integration with CAM-systems (Computer-Aided Manufacturing). One of the main tasks solved by CAM systems is the development of control programs for $\mathrm{CNC}$ machines.

Many software developers for automation of design and technological preparation of production have already equipped their systems with appropriate modules.

Firm "Ascon" has integrated into the system of three-dimensional modeling KOMPAS-3D module $\mathrm{CNC}$, which allows you to receive control programs for various types of processing.

Firm "Top-Systems" has supplemented the T-FLEX CAD computer-aided design system with the T-FLEX CNC option.

\section{Purpose of the study}

These circumstances pose an urgent task for higher educational institutions to introduce the study of integrated CAD/CAM systems into the educational process of training design engineers. In this case, the emphasis should be placed on the practical mastery of the skills of developing control programs using a 3D-model of the manufactured part.

At the stage of choosing an automated system for obtaining control programs for further use in the educational process of the Sukhoi State Technical University of Gomel, the technique described in [9] was used.

\section{The sequence of the research}

Preparation for implementation in the educational process of designing using $\mathrm{CAD} / \mathrm{CAM}$ systems consisted of the following stages:

1. Purchase of licensed software for 20 users, namely, T-FLEX CAD 3D and T-FLEX CNC 3D systems.

2. Installation and adaptation of the specified software to the conditions of use in the educational process of the Sukhoi State Technical University of Gomel. 
3. Preparation of educational and methodological literature containing guidance on the use of a CAD / CAM system in course and diploma design. The features of this stage are described in [10].

The study of the possibility of using a CAD / CAM system in the training of design engineers was carried out by students of the specialty 1-53 0101 "Automation of technological processes and production (by directions)" when performing a course project in the discipline "Automated systems for technological preparation of production" and when completing a diploma project.

The development of the control program was carried out in the T-Flex CAD computer-aided design system using the T-FLEX: CNC option.

To obtain the control program, the following steps were performed:

1. Using the "Tool Editor" command, a cutting tool with the required parameters was created and saved in a file with the ".too" extension (Fig. 1);

2. On the toolbar, the command "Drilling 5D" was selected, and in it the name of the operation, the tool, the surface relative to which the machining is performed and the drilling parameters (depth, speed, feed, etc.). The results of this processing are shown in Fig. 2-4;

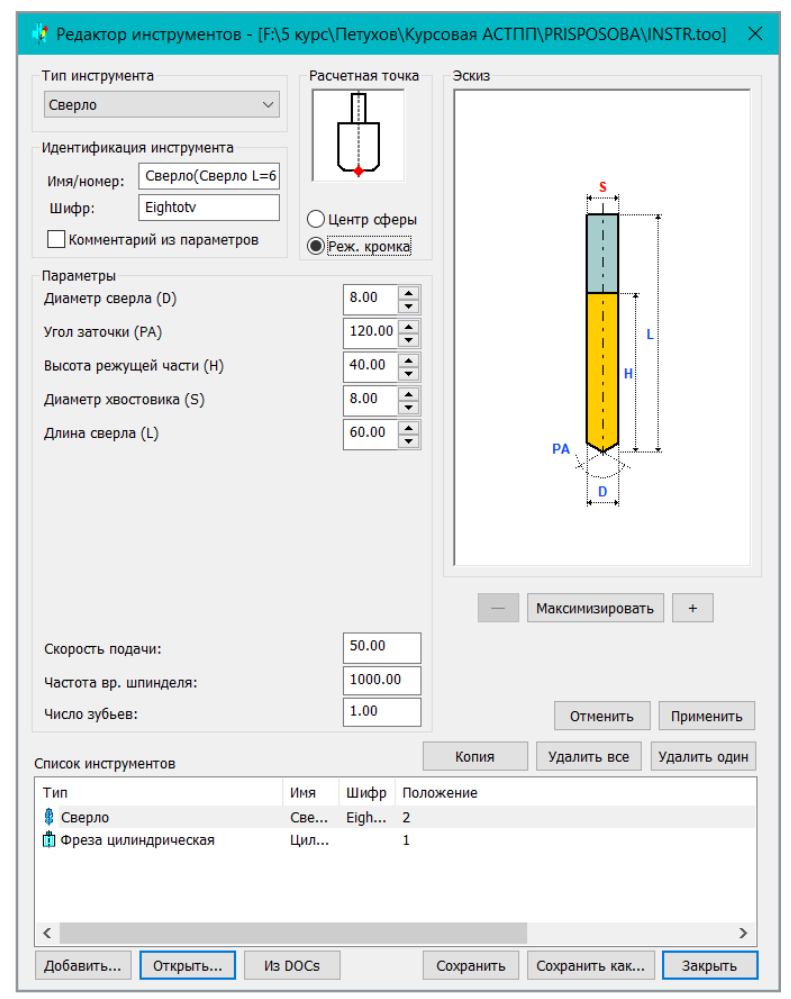

Fig. 1. Tool editor

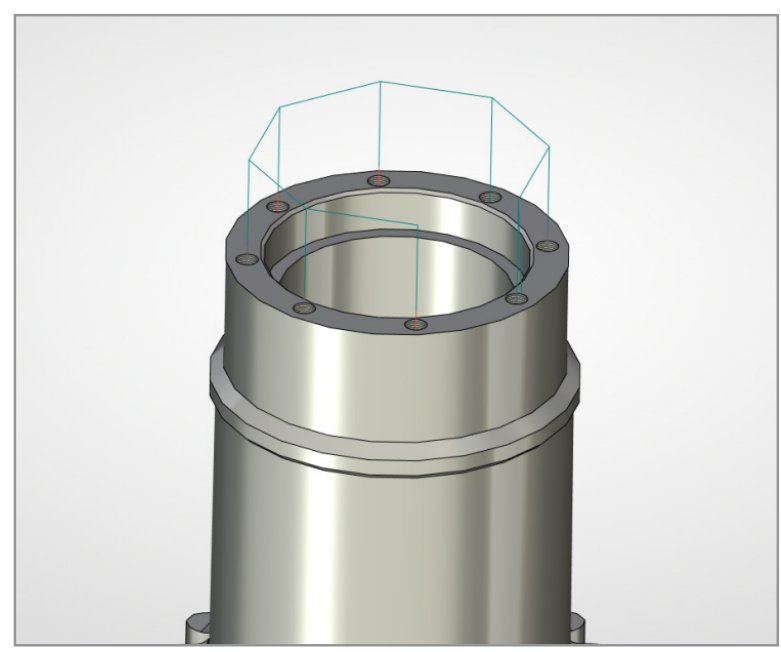

Fig. 2. Vector diagram of drilling

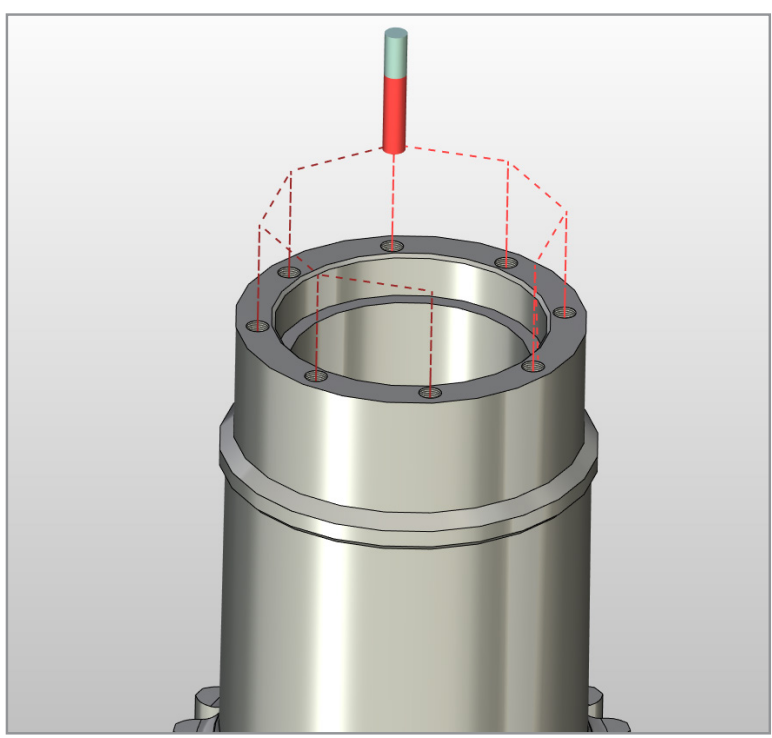

Fig. 3. Drill in start position (Block N105)

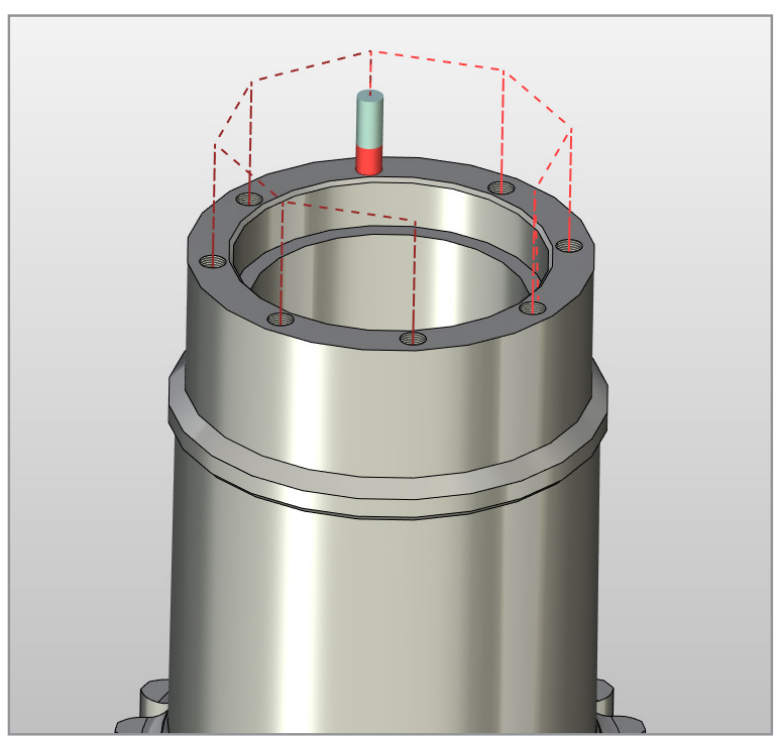

Fig. 4. Drill in end position (Block N115) 
3. On the toolbar, the command "3D milling" was selected, and in it the name of the operation, the tool, the face that will be milled, the angle of inclination of the tool, the type of pass and the milling parameters (depth, speed, feed, etc.). The results of this processing are shown in Fig. 5-7;

4. To check the developed program, the "Processing simulator" command was launched, during which the tool path was presented in the form of a video;

5. The result obtained in the form of a control program presented in fig. 8 was saved in a file for transfer to the machine.

6. To check the developed program, the "Processing simulator" command was launched, during which the tool path was presented in the form of a video.

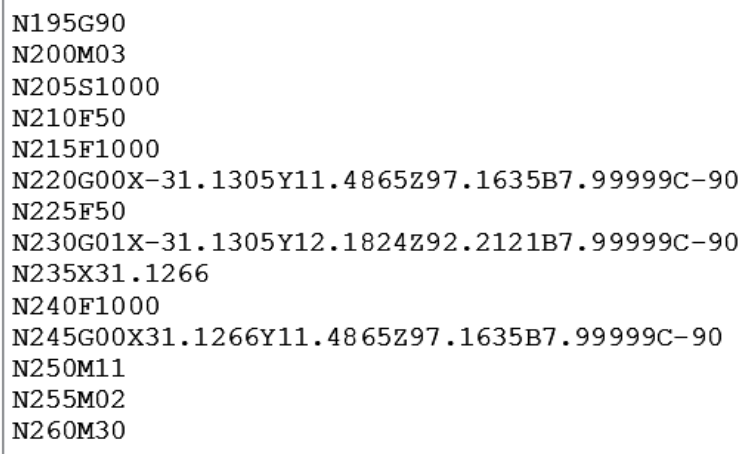

Fig. 8. Listing of the control program: Operation 030 Horizontal milling (Cylindrical mill L=80 D=30)

\section{Conclusion}

The introduction of an integrated design system into the educational process has shown not only the possibility of obtaining a control program for a CNC machine tool, but also the practical implementation of this possibility by students on the basis of licensed software. The results, in the form of control programs obtained in the course of diploma design using integrated $\mathrm{CAD} / \mathrm{CAM}$ systems, were highly appreciated by the members of the State Examination Commission

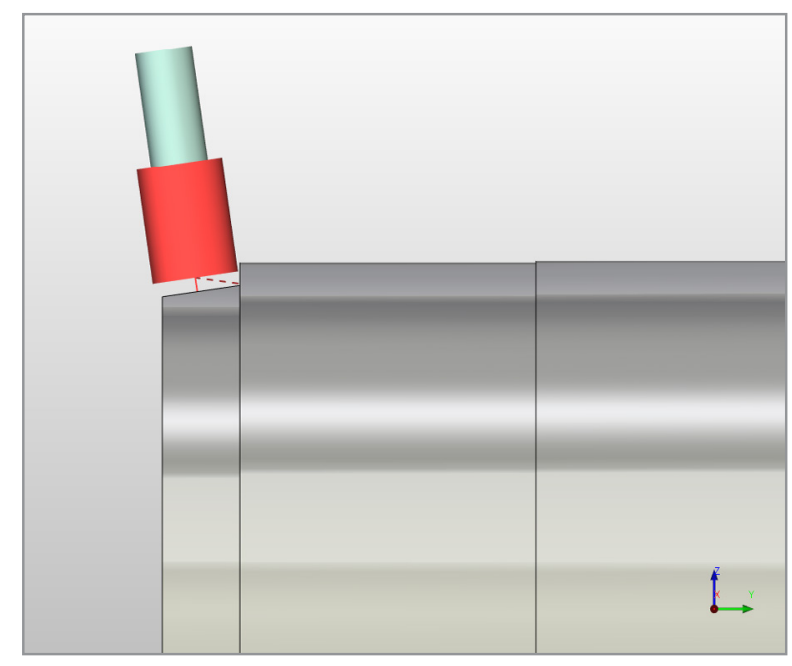

Fig. 5. Approach cutter (Block N220)

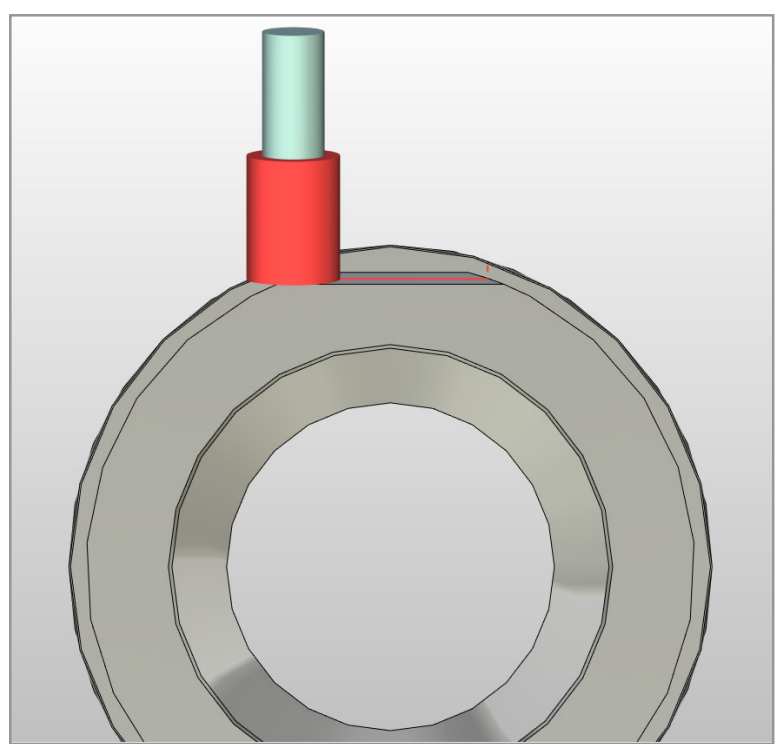

Fig. 6. Bevel milling (Blocks N230-N235)

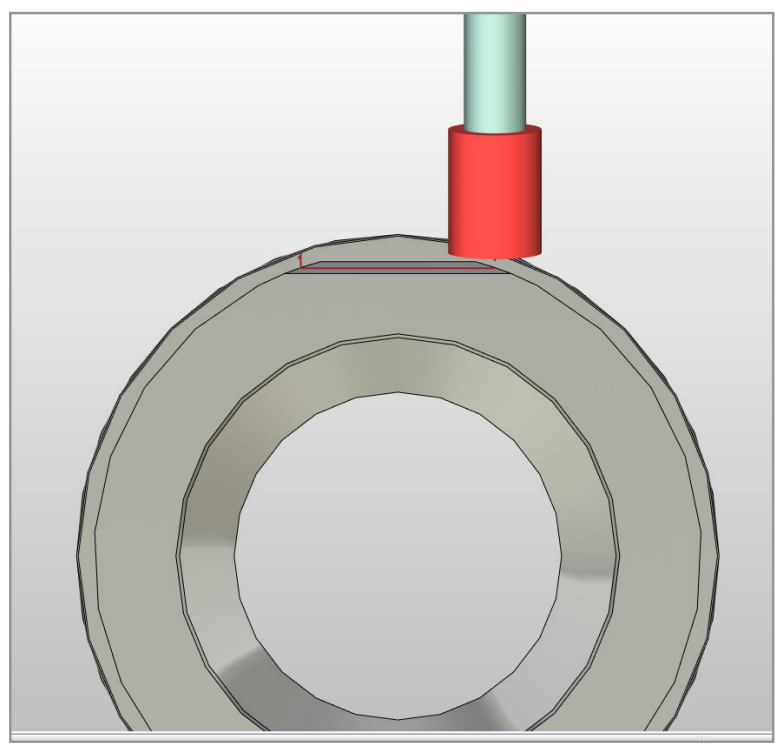

Fig. 7. Cutter retraction (Block N245)v 


\section{REFERENCES}

1. Akulovich L.M., Sheleg V.K. Osnovy avtomatizirovannogo proektirovaniya tekhnologicheskih processov v mashinostroenii [Fundamentals of computer-aided design of technological processes in mechanical engineering]. Minsk: New knowledge Publ., 2012.- 488 p. (in Russian).

2. Epifanova O.V., Troickij D.I. Avtomatizaciya tekhnologicheskoj podgotovki proizvodstva detalej, izgotavlivaemyh na oborudovanii s CHPU [Automation of technological preparation for the production of parts manufactured on CNC equipment]. Izvestiya TulGU. Tekhnicheskie nauki [Izvestiya TulGU. Technical science] № 3. Tula: TulGU Publ., 2011.p. 53-61. (in Russian).

3. Epifanova O.V., Troickij D.I. Metodika optimal'nogo vybora struktury CAM-sistemy [Methodology for the optimal selection of the structure of the CAM system] Izvestiya TulGU. Tekhnicheskie nauki [Izvestiya TulGU. Technical science] № 3. Tula: TulGU Publ., 2011.- p. 21-29. (in Russian).

4. Grabchenko A.I., Vnukov Yu. N., Dobroskok V.L. Integrirovannye generativnye tekhnologii [Integrated Generative Technologies]. Kharkiv: National Technical University «Kharkiv Polytechnic Institute» (NTU «KhPI») Publ., 2011.416 p. (in Russian).

5. Oficial'nyj sajt firmy ASKON [ASCON official website] Available at: www.ascon.ru (accessed: 12.11.2013) (in Russian).

6. Oficial'nyj sajt kompanii «Top Sistemy» [Official site of the company "Top Systems"] Available at: www.tflex.ru (accessed: 12.11.2013) (in Russian).

7. Oficial'nyj sajt kompanii INTERMEKH [The official website of the company INTERMEX] Available at: www.intermech. ru (accessed: 12.11.2013) (in Russian).

8. Pestrecov S.I. CALS-tekhnologii v mashinostroenii: osnovy raboty v CAD/CAE-sistemah [CALS-technologies in mechanical engineering: the basics of working in CAD / CAE-systems] Tambov: Tambov State Technical University Publ., 2010.- 104 p. (in Russian).

9. Petukhov A.V. Formalization of the problem of selection of automated system. «System analysis and applied information science». 2018;(1):16-20. https://doi.org/10.21122/2309-4923-2018-1-16-20

10. Petukhov A.V. Digital Transformation of Technological Design in the Preparation of Design Engineers: History and Prospects. Digital Transformation. 2020;(1):57-72. https://doi.org/10.38086/2522-9613-2020-1-57-72

11. Poletaev V.A. Komp'yuterno-integrirovannye proizvodstvennye sistemy: uchebnoe posobie [Computer-integrated production systems: study guide] Kemerovo. Kuzbass State Technical University Publ., 2011. 201 p. (in Russian).

12. Ruseckij A.M., Vityaz' P. A., Hejfec M.L. Avtomatizaciya i upravlenie v tekhnologicheskih kompleksah [Automation and control in technological complexes]. Minsk: Belarusian Science Publ., 2014.- 375 p. (in Russian).

\section{ЛИТЕРАТУРА}

1. Акулович, Л.М. Основы автоматизированного проектирования технологических процессов в машиностроении: учеб. пособие / Л.М. Акулович, В.К. Шелег.- Минск: Новое знание; М.: МЕФРА-М, 2012.- 488 с.

2. Епифанова О.В., Троицкий Д.И. Автоматизация технологической подготовки производства деталей, изготавливаемых на оборудовании с ЧПУ // Известия ТулГУ. Технические науки. Вып. 3. Тула: Изд-во ТулГУ, 2011.- с. 53-61

3. Епифанова О.В., Троицкий Д.И. Методика оптимального выбора структуры САМ-системы // Известия ТулГУ. Технические науки. Вып. 3. Тула: Изд-во ТулГУ, 2011.- с. 21-29

4. Грабченко, А.И. Интегрированные генеративные технологии: учеб. пособие [для студ. выс. учеб. заведений] / А.И. Грабченко, Ю.Н. Внуков, В.Л. Доброскок; под ред. А

5. Официальный сайт фирмы АСКОН / АСКОН // [Электронный ресурс].- 2013.- Режим доступа: www.ascon.ru Дата доступа: 12.11.2013 г.

6. Официальный сайт компании «Топ Системы» / Топ Системы // [Электронный ресурс].- 2013.- Режим доступа: www.tflex.ru - Дата доступа: 12.11.2013 г.

7. Официальный сайт компании ИНТЕРМЕХ / ИНТЕРМЕХ // [Электронный ресурс].- 2013.- Режим доступа: www. intermech.ru - Дата доступа: 12.11.2013 г.

8. Пестрецов, С. И. CALS-технологии в машиностроении: основы работы в CAD/CAE-системах: учебное пособие / С.И. Пестрецов.- Тамбов: Изд-во ГОУ ВПО ТГТУ, 2010.- 104 с.

9. Петухов А.В. Формализация задачи выбора автоматизированной системы. «Системный анализ и прикладная информатика». 2018;(1):16-20. https://doi.org/10.21122/2309-4923-2018-1-16-20

10. Петухов А.В. Цифровая трансформация проектирования технологических процессов при подготовке инженеровпроектировщиков: история и перспективы. Цифровая трансформация. 2020;(1):57-72. https://doi.org/10.38086/25229613-2020-1-57-72

11. Полетаев, В.А. Компьютерно-интегрированные производственные системы: учеб. пособие / В.А. Полетаев - Кемерово, Кузбас. гос. техн. ун-н., 2011.-201 с.

12. Автоматизация и управление в технологических комплексах / А.М. Русецкий [и др.]; под общ. ред. А.М. Русецкого.- Минск: Беларуская Наука, 2014.- 375 с.

Поступила

18.12 .2020
После доработки

01.03 .2021
Принята к печати

01.03 .2021 
ПЕТУХОВ А. В.

\section{ВНЕАРЕНИЕ ИНТЕГРИРОВАННЫХ СИСТЕМ ПРОЕКТИРОВАНИЯ В УЧЕБНЫЙ ПРОЦЕСС}

Учреждение образования «Гомельский государственный технический университет имени П. О. Сухого», 2. Гомель, Республика Беларусь

Современный этап развития САD-систем (Сотритеr-Aided Design) характеризуется значительным расширением сфер их использования. Интересным направлением совершенствования СAD-систем является их интеграция с САМ-системами (Сотриter-Aided Manufacturing). Одной и главных задач, решаемых САМ-системами, является разработка управляющих программ для станков с ЧПУ.

Многие разработчики программного обеспечения для автоматизации конструкторско-технологической подготовки производства уже оснастили свои системы соответствующими модулями.

Указанные обстоятельства ставят перед выстими учебными заведениями актуальную задачу ввести изучение интегрированных САD/САМ-систем в учебный процесс подготовки инженеров-проектировщиков. Упор при этом нужно сделать на практическое овладение навыками разработки управляющих программ с использованием 3D-модели изготавливаемой детали.

Описаны этапы подготовки к внедрению системы, начиная с анализа рынка необходимых программных продуктов и заканчивая адаптацией лицензированной системы к условиям использования в учебном проиессе университета. Дается ссылка на описание методики, используемой при оценке автоматизированных систем на стадии, предшествующей проведению тендера на их закупку. Подчеркнуто, что исследование возможности использования САD/ САМ-системы при подготовке инженеров-проектировщиков было проведено студентами при выполнении курсового и диплоного проектов по дисииплине «Автоматизированные системы технологической подготовки производства». Приводится методика проектирования управляющих программ, используемая студентами, и дается оченка полученных результатов.

Ключевые слова: подготовка инженеров-проектировщиков, управляющяая программа, САD/САМ-система, программно-управляемое оборудование.

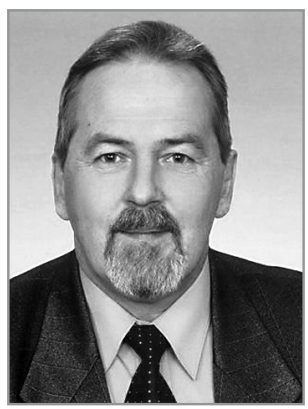

Петухов Александр Владимирович - старший преподаватель кафедры «Технология машиностроения» учреждения образования «Гомельский государственный технический университет имени П.О. Сухого»

Petuhov Aleksandr Vladimirovich Senior lecturer of the chair «Technology of mechanical engineering» of the Sukhoi State Technical University of Gomel. E-mail: Petukhov@tut.by 